\title{
'N TOEKOMS VIR DIE CHRONIES GEESTESVERSTEURDE
}

\section{SUMMARY}

The Lodge programme was started at the Austin State Hospital a few years ago to train chronically mentally ill patients, who would otherwise have spent the rest of their lives in hospital, to become independent members of the community.

It is an intensive training program for which patients are carefully selected. Significant aspects are that the patients function as members of a problem-solving group and are taught cleaning skills with which they earn an income. There are five levels of progress in the first phase, on completion of which the group graduates from the programme. In the second phase the group moves into a house in the community and continues with cleaning contracts for at least a year before individual members may withdraw.

\section{INLEIDING}

Sy stap die hospitaalkantien doelgerig binne. Sy glimlag skelmpies en gesels aanmekaar met iemand wat vir niemand anders sigbaar is nie. By elke tafel staan sy 'n rukkie stil en ledig die asbakkie in 'n stukkie toiletpapier. Dan gaan sit sy in die hoekie van die vertrek en begin rustig die laaste flentertjies tabak uit die sigaretstompies krap om 'n nuwe sigaret vir haarself te rol. Haar vingerpunte is swart van al die nikotien. Sy sê dit is so omdat die verpleegsters elke oggend haar vingerpunte aan die brand steek om haar weer lewendig te maak. "Mens kan nooit versigtig genoeg hier wees nie," verduidelik sy aan een van die ander pasiënte, "snags haal die verpleegsters pêrels uit die pasiënte se liggame." Die enigste rede waarom sy in die hospitaal bly, sê sy, is omdat al 1,342 van haar gesins- en familielede buite die hospitaalgronde vermoor is.

Daar is nie plek in die buitelewe vir haar of vir die nagenoeg 800 ander pasiënte soos sy nie. Omdat sy in 'n wêreld van haar eie leef wat so verskil van die van die meerderheid, lei sy 'n beskermde bestaan

\section{MIRINDA COETSEE BA (Verpl) PU vir CHO, MSN Texas Woman's Uni- versity, DVO Pretoria, DSN University of Alabama Direkteur van Verpleegdienste, Austin Staats- hospitaal en deeltydse Professor aan die Univer- siteit van Texas}

in 'n beperkte omgewing, miskien vir die res van haar lewe. Die merke op haar gewrigte en keel is stille getuies van die pyn wat sy in die buitewêreld beleef het, 'n wêreld waarna sy nie wil terugkeer nie.

Met ou Jan kan sy lekker gesels. $\mathrm{Hy}$ is 34 jaar oud, en dis nou sy twintigste besoek aan die hospitaal. Die patroon is altyd dieselfde. Hy doen goed in die hospitaal, neem deel aan al die terapeutiese programme en aktiwiteite en word ontslaan. $\mathrm{Na}$ 'n paar weke se doellose ronddwaal in die strate bring die polisie hom terug na die hospitaal Jan se gesin het hom jare gelede reeds verwerp. Hy kan nie 'n werk behou nie. Die hospitaalpersonee is al wat hy het. Hy is gelukkig hier.

\section{OORSIG VAN DIE LODGEPROGRAM}

Dié is twee van die talle pasiënte wie se toekoms uitsigloos was. Hulle diepe afhanklikheid van ander, vrees vir die buitewêreld, onwilligheid om verantwoordelikheid vir hulself te aanvar en hul onvermoë om selfs die geringste probleme aan te pak en ' $n$ besluit te neem, het hulle tot 'n lewenslange verblyf in die hospitaal verdoem.

Die Lodge-program is 'n paar jaar gelede by Austin-staatshospitaal op die proef gestel in ' $n$ poging om hierdie pasiënte weer nuttige burgers van die samelewing te maak. Die program is gebaseer op die navorsingswerk van Fairweather $(1,2)$. Dit beoog om die af- hanklikheidsgevoel van die pasiënte te oorkom deur 'n intensiewe opleidingsprogram wat die pasiënte in staat stel om die volgende oogmerke tydens hul verblyf in die hospitaal te bereik:

- om 'n aanvaarbare persoonlike voorkoms te behou

- om persoonlike besittings en omgewing in goeie orde te hou.

- om geld te verdien deur werkkontrakte binne en buite die hospitaal te aanvaar

- om nuwe werkvaardighede aan te leer

- om daaglikse kommunikasie met ander te verbeter.

\section{EERSTE FASE VAN DIE PRO- GRAM}

Personeel in ander hospitaaleen hede beveel pasiënte vir die Lodgeprogram aan. Logiese kandidate vir die program is gewoonlik:

- 'n persoon met 'n geskiedenis van chroniese afhanklikheid, en met 'n swak werkrekord of geen werkrekord nie

- 'n persoon wat voortdurend in en uit die hospitaal is, of reeds vir 'n lang tydperk gehospitaliseer is

- 'n persoon sonder gesinsverbande, wat destruktiewe gesinsverhoudinge het, of met gesinslede wat nie in hom belangstel nie

- 'n persoon wat in 'n sekere mate gewillig is om onder toesig te werk.

Die personeel aanvaar gewoonlik nie die volgende tipe pasiënte in die program nie: 
- pasiënte wat weghardloop wanneer hulle te angstig of te gefrustreerd raak, of wat nie in staat is om in 'n oop, ongeslote eenheid te bly nie

- pasiënte met 'n onlangse geskiedenis van aggressiewe gedrag

- pasiënte met fisiese ongesteldhede van 'n ernstige aard soos kardio-vaskulêre probleme, ongekontroleerde epilepsie of diabetes wat spesiale sorg vereis

- pasiënte jonger as 18 en ouer as 55 jaar

- getroude pasiënte wat by hul gesinne wil bly

- psigopate en chroniese verdowingsmiddelverslaafdes

- pasiënte wat sê dat hulle selfmoordneigings het of onlangs pogings aangewend het om selfmoord te pleeg.

'n Groepie van ses tot agt chronies geestesversteurde pasiënte word in die Lodge-program opgeneem. Saam ondergaan hulle 'n periode van ses tot nege maande intensiewe opleiding waarin hulle instruksie in, onder andere, die volgende ontvang:

- klere, voorkoms en higiëne

- kommunikasievaardighede

- kookkuns

- hoe om 'n besluit te neem

- geldsake

- noodhulp

- stokperdjies

- in en om die huis

- geestesgesondheid

- huidige wêreldgebeure

- selfmedikasie en die beheer van epileptiese aanvalle

- alkoholbewustheid

- sosiale en politieke sake ontspanning

Gedurende die eerste fase leer die pasiënte om kommersiële skoonmaakwerk te verrig. Hulle begin geleidelik om werk in die hospitaal, waarvoor hulle vergoed word, te aanvaar. Wanneer hulle die nodige vaardigheid onder toesig bereik, aanvaar hulle as 'n groep skoonmaakwerkkontrakte in die gemeenskap.

\section{Kommunikasie}

Die sleutel tot die sukses van hierdie program lê daarin dat die pasiënt daagliks as lid van 'n groep werk en leef. Die groep kies sy leiers wat vir verskillende aktiwiteite verantwoordelik is. Die groepsvoorsitter help die ander lede om werkvaardighede te ontwikkel. Hy luister na probleme en idees en help die groep om besluite te neem. Die groepsekretaresse skryf 'n kort opsomming van die besluite wat tydens elke groepbespreking geneem is en verwittig die personeel daarvan. Die werkshoof is verantwoordelik vir die kwaliteit van die groep se werk. Hy is die middelman tussen die groep en die personeel wat die opleiding behartig. Die medikasievoorsitter sien toe dat al die lede hulle medikasie neem en rapporteer aan die verpleegkundige indien die groeplede nie betyds vir medikasie aanmeld nie, of weier om dit te neem. Dit is ook sy verantwoordelikheid om die verpleegkundige in kennis te stel wanneer die voorraad leegloop.

Om te verseker dat die groep in 'n hegte, outonome, probleemoplossende groep ontwikkel, is dit noodsaaklik dat daar 'n gestruktureerde formele kommunikasiestelsel bestaan wat voorkom dat die personeel aanvanklik onnodig die groep se besluite beïnvloed of hulle van raad voorsien. Die kern van hierdie kommunikasiestelsel is notas wat die personeel aan die pasiënte rig. Die nota is 'n kort stelling van die probleem sonder enige aanduiding wat die groep moet doen om die probleem op te los.

Die groepie wat hulself die arende noem, kom byvoorbeeld een aand terug van hul groepskoonmakkwerk en vind 'n nota in hul posbus wat sê: $M n r$ Smit het om 4 $\mathrm{nm}$ na die hospitaal teruggekeer. $\mathrm{Hy}$ het na alkohol geruik en was onvas op sy voete. Die groepie hou 'n vergadering en bespreek die probleem met mnr Smit. Dan rig hulle 'n nota aan die personeel wat inligting oor die volgende bevat:

- wat mnr Smit gaan doen om die probleem te voorkom

- hoe die groep mnr Smit gaan straf vir die oortreding

- wie die spesifieke straf voorgestel het

- wanneer, waar en hoe die straf sal plaasvind

- wie sal toesien dat die straf uitgevoer word.

Die notas word net geskryf oor gedrag wat die personeel as onvanpas of onverantwoordelik beskou. Alhoewel die personeel nie die pasiënte se probleme vir hulle probeer oplos of probeer raad gee nie, tree hulle op as konsultante vir die pasiënte. As die arende byvoorbeeld besluit dat mnr Smit nie vir die volgende drie maande 'n naweekpas kan kry nie, dat hy ekstra werk vir die volgende maand moet verrig en nie sy vrou vir die volgende twee weke kan sien nie, en die personeel meen die aanbeveling van die arende is onvanpas, stuur hulle die nota terug aan die arende om die probleem te hersien. Die groep tree nooit teenoor 'n medegroepslid op voordat die personeel hul plan van aksie geëvalueer het nie. Die groep word volgens die gepastheid van hul besluit geëvalueer, en nie of hulle daarin slaag of misluk om die individuele groepslid se gedrag te beheer nie.

Die groep evalueer ook die individuele lede se vordering en beveel by die personeel aan of ' $n$ groepslid meer voorregte moet ontvang of dat sekere voorregte weerhou moet word.

Die personeel vergader weekliks en hersien al die groepe se aanbevelings. Die personeel let veral op na die werklikheid en gepastheid van die aanbevelings asook die mate van verantwoordelikheid wat die groepslede vir mekaar neem, en bespreek dit met die groep. Indien die groep nie goed funksioneer nie, en nie kan demonstreer dat hulle 'n probleem kan aanpak en oplossings daarvoor probeer vind nie, en oor die algemeen nie volgens standaard optree nie, kan die personeel die hele groep penaliseer deur hulle na 'n laer vorderingsvlak af te bring.

\section{Vorderingsvlakke}

Die program bestaan uit vyf vorderingsvlakke. Op elk van die vlakke moet die pasiënte sekere pligte nakom, waarvoor hul vergoed word.

Die eerste vlak het basiese kriteria, soos dat die individu soggens voor sewe-uur gereed moet wees vir ontbyt, sy kamer moet aan die kant wees en hy moet betyds vir al die klasse opdaag en aan al die klasse deelneem. Hy moet sy eie medikasie onder toesig kan neem en hom aan al die regulasies onderwerp. Wanneer hy hierdie kriteria vir 'n tydperk nakom, kan hy byvoorbeeld $\$ 10$ per week uit die trustfonds trek en 'n halfdagpos gedurende 'n Saterdag kry. Hy mag vry op die hospitaalgronde rondbeweeg en die telefoon Saterdae gebruik.

Wanneer pasiënte die tweede vlak bereik, ken hulle al die groepslede se name en kan hulle nuwe lede help om by die program in te skakel. Op hierdie vlak moet hulle al hul werk volgens standaard voltooi, aan alle groepsvergaderings deelneem en voorstelle aan die hand doen. Voorregte word hiervolgens toegeken. 
Pasiënte op die derde vlak neem aktief in klasse deel en begin om groepsbesluite te neem en probleme op te los. Op hierdie vlak toon groepslede 'n ondersteunende belangstelling in mekaar deur na ander se probleme te luister en ' $n$ vriend in nood te wees.

'n Pasiënt wat in staat is om konstruktiewe kritiek te gee en te ontvang, gewillig is om as 'n groepsleier op te tree en om ekstra werk en verantwoordelikhede te aanvaar, is op die vierde vlak van ontwikkeling. Die pasiënt se gedrag word beloon met naweekpasse, die gebruik van die klein kombuisie om versnaperinge voor te berei, $\$ 20$ per week uit die trustfonds en ruim geleentheid vir ontspanning en besoeke aan aktiwiteite in die stad.

Binne enkele maande kan die pasiënt vorder tot die vyfde vlak waarop hy voortdurend 'n goeie voorbeeld aan al die ander Lodgelede moet stel, gewillig moet wees om met al die opleidingsklasse te help, en in staat moet wees om groepsdoelwitte op te stel en te evalueer. Wanneer die pasiënt hierdie vlak bereik, mag hy $\$ 27$ per week uit die trustfonds trek, een klas per week oorslaan, 5 uur per week vakansie neem en naweekpasse neem sonder toestemming van die personeel.

Wanneer pasiënte die vyfde vlak bereik voldoen hulle aan die volgende verwagtinge, wat hulle in staat stel om van die program te gradueer:

- om te alle tye 'n skoon en netjiese voorkoms te behou, eie wasgoed te kan doen, en kamer skoon en netjies te hou

- aktiewe deelname aan groepsvergaderings. Toepaslike en effektiewe kommunikasie met ander, konfronteer en ondersteun ander groepslede, en help om groepsbesluite te neem
- neem medikasie onder toesig van die medikasievoorman en ken die name, hoeveelhede en tye wanneer die medisynes geneem moet word

- voltooi alle werk wat aan hom toegewys word, dra goeie kennis van en is vaardig in skoonmaakwerk en is in staat om as ' $n$ lid van 'n groep en onder toesig te werk

- open 'n tjek- en spaarrekening. Is in staat om geld te deponeer en te onttrek. Het goeie geldbeplanningsvaardighede

- is in staat om die bus van en na ' $\mathrm{n}$ bestemming te haal sonder om te verdwaal. Is bekend met die gemeenskap en die dienste wat aangebied word

- is in staat om 'n gebalanseerde maal te beplan en voor te berei

- het 'n goeie kennis van basiese noodhulp

- het die vermoë om gedrag te beheer wat die program en sy werk negatief beinvloed en wat nie aanvaarbaar in die publiek is nie.

\section{TWEEDE FASE}

Wanneer die sowat ses tot agt lede in die groep die vyfde vorderingsvlak vir 'n tydperk bemeester het, is hulle gereed om saam na 'n huis in die gemeenskap te trek. Hulle gaan met hul werkkontrakte voort en vind nuwe kontrakte op hul eie. Hulle behou die verantwoordelikheid om alle huishoudelike sake self te beheer en om besluite oor enige belangrike sake self te neem. Wanneer hulle in hul huis gevestig is, is kontak met die hospitaalpersoneel minimaal.

Die lede sluit 'n kontrak met mekaar dat hulle vir minstens een jaar sal saambly. Hulle het 'n jaar se kontrak op die huis en 'n jaar se skoonmaakkontrakte om te vol- voer. Daarna mag 'n lid uit die groep onttrek en ander werk aanvaar. Die groepslede is nou onafhanklike lede van die samelewing. Hulle word voorsien van 'n motor waarvoor hulle die onderhoudkoste betaal. Die hospitaal voorsien ook die dienste van 'n verpleegster, maatskaplike werker en psigiater indien die groep daarvoor vra.

\section{EVALUERING VAN DIE PROGRAM}

Vandat hierdie program ses jaar gelede by Austin se staatshospitaal in werking gestel is, het 18 groepe die program voltooi. Sowat $250 \mathrm{pa}$ siënte wat die res van hul lewe in die hospitaal sou deurbring, woon nou onafhanklik in die samelewing en verrig 'n nuttige dag se werk. Hertoelating van hierdie pasiënte tot die hospitaal het nog net een keer in die ses jaar voorgekom.

Die sukses van hierdie program word toegeskryf aan die feit dat die pasiënte van werkvaardighede, wat ' $n$ tasbare vergoeding is om in kontak met die werklikheid te bly voorsien word. Die ander belangrike faktor is die sosiale steun wat hulle na die nuwe omgewing volg en bybly. Die program se fokus is nie die verwydering van die pasiënt se simptome nie, maar 'n opleidingsprogram wat die pasiënt leer om te voorkom dat die simptome sy gedrag beheer. Die program se reëls en regulasies verbied delusionele gesprekke wat met effektiewe werkverrigting inmeng, en verbied die pasiënt om in die publiek te hallusineer. Die gemotiveerde pasiënt kan hierdie simptome beheer

\section{REFERENCES}

1. Fairweather. G W; Simon. R ef al Relative effectiveness of psychotherapeutic programs: a multicriteria comparison of four programs for three different patient groups. Psychological Monographs, 1960. 74, (whole no. 492)

2. Fairweather, G W. (ed). Social Psychology in Treating Mental Illness, Wiley, New York 1964

\section{BOOK REVIEW}

BOEKRESENSIE

\section{NURSING SKILLS FOR HUMAN NEEDS \\ Maria Cooley, (R.N. M.S.) and Carol Shaf- fer, (R.N. M.S.) \\ Reston Publishing Co. Virginia}

A well written book aimed at outlining principles regarding nursing skills, based on human needs. The accent throughout falls on human needs and objectives have been provided with regard to every procedure described.
The text provides all the underlying principles necessary for a thorough understanding of each skill. All basic nursing procedures have been described together with very valuable sketches and photographs. Throughout, any ethical aspects or possible medico-legal hazards have been brought to the attention of the reader together with preventative measures.

A most valuable book for any nurse as a reference manual, and could be most valuable as a reference book in every nursing unit.

C Lindenburg 